\title{
Article \\ DMI-Fungicide Resistance in Venturia nashicola, the Causal Agent of Asian Pear Scab-How Reliable Are Mycelial Growth Tests in Culture?
}

\author{
Hideo Ishii ${ }^{1,2,3, *(\mathbb{D}) \text {, Hans Jorgen Cools }}{ }^{4}$, Kumiko Nishimura ${ }^{2}$, Lorenzo Borghi ${ }^{5}$ (D), Kenji Kikuhara ${ }^{6}$ \\ and Yuichi Yamaoka 1
}

check for

updates

Citation: Ishii, H.; Cools, H.J.;

Nishimura, K.; Borghi, L.; Kikuhara,

K.; Yamaoka, Y. DMI-Fungicide

Resistance in Venturia nashicola, the

Causal Agent of Asian Pear Scab

- How Reliable Are Mycelial Growth

Tests in Culture? Microorganisms 2021,

9, 1377. https://doi.org/10.3390/

microorganisms 9071377

Academic Editors:

Dolores Fernández-Ortuño,

Guido Schnabel and

Anne-Sophie Walker

Received: 21 May 2021

Accepted: 21 June 2021

Published: 24 June 2021

Publisher's Note: MDPI stays neutral with regard to jurisdictional claims in published maps and institutional affiliations.

Copyright: (C) 2021 by the authors. Licensee MDPI, Basel, Switzerland. This article is an open access article distributed under the terms and conditions of the Creative Commons Attribution (CC BY) license (https:// creativecommons.org/licenses/by/ $4.0 /)$.
1 Faculty of Life and Environmental Sciences, University of Tsukuba, Tennodai 1-1-1, Tsukuba 305-8572, Japan; yamaoka.yuichi.gp@u.tsukuba.ac.jp

2 National Institute for Agro-Environmental Sciences, Kannondai 3-1-3, Tsukuba 305-8604, Japan; artanaria5@yahoo.co.jp

3 Department of Agriculture, Kibi International University, Sareo 370-1, Shichi, Minami-Awaji 656-0484, Japan

4 Syngenta, Jealott's Hill International Research Centre, Bracknell RG42 6EY, UK; hans.cools@syngenta.com

5 Syngenta Crop Protection AG, Werk Stein, Schaffhauserstrasse, WST.820.2.79, CH-4332 Stein, Switzerland; Lorenzo.Borghi@syngenta.com

6 Fukuoka Agriculture and Forestry Research Center, Yoshiki 587, Chikushino 818-8549, Japan; kikuhara@farc.pref.fukuoka.jp

* Correspondence: hi481204@yahoo.co.jp

\begin{abstract}
Scab, caused by Venturia nashicola, is among the most serious diseases of Asian pears and control of this disease largely relies on sterol demethylation inhibitor (DMI) fungicides. However, pear growers have complained about field performance of DMIs since the mid-2000s. In this study, to evaluate pathogen sensitivity, mycelial growth tests and inoculation tests were conducted using DMI-amended culture medium and fungicide-sprayed potted pear trees, respectively. Results confirmed distribution of isolates resistant to fenarimol, hexaconazole, and difenoconazole in the field populations. Importantly, results from tests in culture did not fully correlate with those from tests in planta. Due to phenotypic instability of resistance and poor sporulation of this pathogen in culture, resistance is generally assessed by laborious and time-consuming inoculation with conidia collected from a field. To improve the result interpretation from in vitro tests, the isolates were genotyped: the CYP51 gene which encodes the target sterol $14 \alpha$-demethylase was sequenced and various mutations have been detected in the coding sequence of DMI-resistant isolates. In addition to the detected single nucleotide polymorphisms, alternative mechanisms, not based on changes in the structure of the target protein, may also increase DMI resistance. Development of molecular methods for the diagnosis of DMI resistance seems to be challenging in V. nashicola.
\end{abstract}

Keywords: CYP51; DMIs; fungicide resistance; pear scab; sensitivity tests; Venturia nashicola

\section{Introduction}

Asian pears such as Japanese pear (Pyrus pyrifolia var. culta) and Chinese pears (P. bretschneideri and P. ussuriensis), distinct from European pear (P. communis), are widely grown in East Asia [1]. Scab, caused by the ascomycete Venturia nashicola [2,3], is among the most serious diseases of Asian pears [4] but is not known to occur outside Asia. Consequently, $V$. nashicola is a quarantined pathogen in many countries [5,6].

To control this disease, growers largely rely on spray applications of fungicides because there are very few commercially acceptable cultivars with scab resistance $[4,7,8]$. However, the frequent use of benzimidazole (MBC) fungicides resulted in resistance development in the pathogen in the mid-1970s $[9,10]$. As a result, various sterol demethylation inhibitor (DMI) fungicides including triflumizole, bitertanol, fenarimol, hexaconazole, fenbuconazole, difenoconazole and others, targeting the P450 sterol 14 $\alpha$-demethylase (CYP51) 
protein [11,12], have been registered and sprayed during blossom and after flowers fall since 1986 in Japan [10,13].

Sterols such as ergosterol, ergosta-5,24(24 $)$-dien-3 $\beta$-ol, and ergosta-5,7-dien-3 $\beta$-ol are important constituents of fungal cell membranes regulating their stability and permeability [14-16]. Therefore, fungicides inhibiting key enzymes involved in fungal sterol biosynthesis including CYP51 have been very effective [11] with DMIs sharing over 30\% of the fungicide market in agriculture worldwide [12]. Resistance to DMIs evolves slowly and resistance levels are often low compared with those for MBC resistance [17]. Despite that, DMI resistance was reported in many pathogens including the related fungus $V$. inaequalis, which causes apple scab, in as early as the 1980s [18-20]. In Japan, to maintain their field performance, it has been advised to limit DMI applications to a maximum of three times per year in a mixture or alternative use with other effective fungicides having a different mode action [13,21]. As a consequence, no clear evidence of DMI resistance had been shown for pear scab until the mid-2000s, about 20 years after their introduction to Japan [10,22].

Meanwhile, methods for testing $V$. nashicola sensitivity to two DMIs triflumizole and bitertanol were developed. A mycelial growth test on fungicide-amended culture medium and comparison of $\mathrm{EC}_{50}$ (50\% effective concentration to inhibit growth) rather than MIC (minimum inhibitory concentration) values was recommended [23]. Using this method, baseline sensitivity was also determined for fenarimol and less-sensitive isolates were detected occasionally in culture, although the performance of DMIs was maintained in planta [24,25]. In the spring 2005, however, pear trees were heavily attacked by scab in commercial orchards located across Fukuoka Prefecture, the southwest of Japan, where growers tended to apply DMIs more frequently than recommended in a spray calendar [26]. Therefore, we tested DMI sensitivity of $V$. nashicola isolates and continued to monitor change of sensitivity in field populations.

Various mechanisms are known to be involved in DMI resistance. They include [11,12] (1) modifications in target enzyme caused by mutations of the CYP51 genes resulting in decreased binding affinity of fungicides, (2) overexpression of CYP51 genes, and (3) decreased intracellular fungicide concentration mediated by increased energy-dependent efflux. For $V$. nashicola, Cools et al. [25] cloned and sequenced the complete CYP51 gene but no alterations were found in the isolates with reduced DMI sensitivity compared with those of wild-type sensitive isolates. Resistance monitoring is extremely laborious and time-consuming for $V$. nashicola isolates because their growth is slow both in culture and in planta. However, molecular mechanism(s) of DMI resistance are currently unknown for this fungus, making it difficult to develop DNA-based methods for diagnosis of resistance.

Therefore, the major objectives of this study were to (1) demonstrate and monitor DMI resistance of $V$. nashicola both in planta and in culture, (2) examine field relevance of reduced sensitivity in culture, (3) confirm instability of resistance, and (4) analyze sequences of the CYP51 gene of resistant and sensitive isolates.

\section{Materials and Methods}

\subsection{Fungal Isolation and Fungicides}

Fifty-six single-spore stock isolates of $V$. nashicola originating from Hebei, China, were used to establish the baseline sensitivity to difenoconazole and hexaconazole. They were originally isolated in 1993 from an orchard where DMI fungicides had never been sprayed and tested for baseline fenarimol sensitivity [24]. Imported samples of leaves were handled according to the Plant Protection Act under the supervision of the Ministry of Agriculture, Forestry and Fisheries (MAFF), Japan. Next, pear leaves or fruit naturally infected with scab were collected arbitrarily from DMI-exposed commercial orchards located in Fukuoka and Saga prefectures, Japan, between 2005 and 2018, and 41 to 52 single-spore isolates obtained from each orchard. Conidia scraped directly from the lesions were suspended in sterile distilled water (DW) using a steel needle. Drops of conidial suspensions were placed on acidified $3 \%$ water agar (Wako, Osaka, Japan) plates and incubated at $15^{\circ} \mathrm{C}$ for 5 to 7 days in the dark. Agar blocks containing single germinated conidia were individually 
cut with a steel needle after microscopic observation and transferred onto potato dextrose agar (PDA, Difco Laboratories, Franklin Lakes, NJ, USA) slants or plates amended with $50 \mathrm{mg} / \mathrm{L}$ of penicillin G potassium salt, $50 \mathrm{mg} / \mathrm{L}$ of streptomycin sulphate, and $0.05 \%$ $(v / v)$ lactic acid. After incubation at $15{ }^{\circ} \mathrm{C}$ for approximately 2 months in the dark, pure cultures were established and stored at $4{ }^{\circ} \mathrm{C}$ until use. Formulated fungicides used in tests were fenarimol (Rubigan ${ }^{\circledR} 12 \%$ wettable powder, Nissan Chemical, Tokyo, Japan), difenoconazole (Score ${ }^{\circledR} 10 \%$ wettable powder, Syngenta), and hexaconazole (Anvil ${ }^{\circledR}$ 2\% flowable, Syngenta). These fungicides were all purchased.

\subsection{Mycelial Growth Tests on Culture Medium}

Single-spore isolates were transferred to PDA plates and incubated at $20{ }^{\circ} \mathrm{C}$ for about 45 days in darkness. Mycelial discs, $4 \mathrm{~mm}$ in diameter, were cut from an actively growing colony margin and transferred onto PDA plates containing each DMI fungicide at $0,0.01$, $0.05,0.1,0.5,1,5,10,50$, and $100 \mathrm{mg} / \mathrm{L}$ of active ingredient (AI). After incubation at $20^{\circ} \mathrm{C}$ in the dark for 21 days, the colony diameter (minus $4 \mathrm{~mm}$ for the disc) of two replicates per treatment was measured using a handheld digital caliper. The values of $\mathrm{EC}_{50}$ were calculated for each isolate by regressing percentage mycelial growth inhibition against the $\log$ of fungicide concentration using software supplied by K. So, ZEN-NOH (Tokyo, Japan). Two baseline-sensitive isolates Baoding 1-1 and Baoding 2-2, derived from Hebei, China, as described above, were included in the tests as a reference. The $95 \%$ confidence interval (95\% CI) of average values, calculated by Microsoft Office Excel (Seattle, WA, USA), was compared. Statistical differences were found when the $95 \%$ CI of the average values did not overlap. The isolates were defined to be less-sensitive to fungicides when the $\mathrm{EC}_{50}$ values exceeded baseline sensitivity levels.

\subsection{Conidia Formation in Culture}

As conidia formation of $V$. nashicola is generally very poor on ordinary agar medium, conidia of this fungus were obtained in culture using the method of Parker et al. [27] after slight modification. This was the best method so far tested. Individual isolates were cultured on PDA plates at $20^{\circ} \mathrm{C}$ in the dark for approximately 1 month. Mycelia were taken from the colony margins and, after removal of the agar medium, homogenized aseptically in sterile DW. Homogenates were spread over the surface of cellophane membranes, previously autoclaved and placed on PDA plates, and incubated at $20^{\circ} \mathrm{C}$ for 1 month under black light blue irradiation.

\subsection{Inoculation of Potted Pear Trees}

For inoculum, conidia that formed on lesions of leaves or in culture were suspended in $0.01 \%(v / v)$ Tween 80 and $0.1 \%(w / v)$ sucrose in DW after washing with centrifugation [3]. As a DMI-sensitive reference, conidia were collected from trees at an experimental orchard in the National Institute for Agro-Environmental Sciences (NIAES), Tsukuba, Japan. The trees had no history of DMI spray treatments. Concentration of conidia was adjusted to approximately $2.5-5.0 \times 10^{5}$ conidia $\mathrm{mL}^{-1}$ and $1.0 \times 10^{5} \mathrm{~mL}^{-1}$ for those from lesions [3] and from culture [4], respectively. The suspensions were stored in a $-30{ }^{\circ} \mathrm{C}$ or a $-80{ }^{\circ} \mathrm{C}$ freezer until use. Young potted Japanese pear trees of Kousui (=Kosui), the most popular and widely grown cultivar in Japan, highly susceptible to scab, were treated using a handheld sprayer until run-off with labelled concentrations of fungicides, fenarimol at $30 \mathrm{mg} / \mathrm{L}$, hexaconazole at $10 \mathrm{mg} / \mathrm{L}$, and difenoconazole at $25 \mathrm{mg} / \mathrm{L}$ of AI. DW was used as a control. One day after treatment, conidial suspensions were either sprayed on both sides of whole young leaves until run-off or dropped on to three sites for each main vein of five fresh leaves as a rule. Inoculated plants were incubated at $20{ }^{\circ} \mathrm{C}$ in a high humidity (RH: 95-100\%) chamber (Koitotron ${ }^{\mathrm{TM}} \mathrm{TH}$; Koito Electric Industries, Shizuoka, Japan) for $48 \mathrm{~h}$ in the dark, and subsequently outside. One or two weeks after inoculation, the same fungicide and DW treatment was repeated because incubation period of scab fungus is 3 to 4 weeks long under optimal conditions and this might influence on residual fungicide efficacy. Three weeks 
and/or 1 month after inoculation, scab development was assessed visually based on the presence or absence of conidial formation on spray-inoculated leaves or droplet-inoculated sites and scab incidence (\%) calculated as (number of sporulating leaves or sporulating sites/number of spray-inoculated leaves or droplet-inoculated sites) $\times 100$. In case of spray inoculation, each leaf was assessed using the following scale: $0=$ no visible symptoms; 1 = pinhole with no sporulation; 2 = chlorotic or necrotic lesions with no sporulation; 3 = moderately or sparsely sporulating lesions; and $4=$ abundantly sporulating lesions, and disease severity was calculated as $[(4 A+3 B+2 C+D) / 4 \mathrm{E}] \times 100$, where $A, B, C$, and $D$ is the number of leaves corresponding to the scales, $4,3,2$, and 1 , respectively, and $E$ is the total number of leaves assessed [28]. Control (\%) by individual fungicides was calculated as [(incidence or disease severity on untreated trees - incidence or disease severity on treated trees)/incidence or disease severity on untreated trees] $\times 100$. Resistance was defined based on reduction in fungicide efficacy in planta.

\subsection{DNA Extraction, Polymerase Chain Reaction (PCR) Amplification and Sequence Analysis of the CYP51 Gene}

Twenty-one single-spore isolates, obtained in 2005, 2017 and 2018, were selected based on the results from mycelial growth and inoculation tests performed in culture and in planta, respectively. Genomic DNA was extracted from culture of these isolates using the DNeasy Plant Mini Kit (Qiagen, Hilden, Germany) according to instructions from the manufacturer or the methods reported previously [29] after slight modification. In the latter case, a piece of PDA with actively growing mycelium was transferred in a $1.5 \mathrm{~mL}$ microtube containing $500 \mu \mathrm{L}$ of lysis buffer [200 mM of Tris- $\mathrm{HCl}, 50 \mathrm{mM}$ of ethylenediaminetetraacetic acid (EDTA), $200 \mathrm{mM}$ of $\mathrm{NaCl}$, and $1 \% n$-lauroylsarcosine sodium salt, $\mathrm{pH}$ 8.0] and homogenized using a plastic pestle and an electric drill. The mixture was incubated at room temperature for $10 \mathrm{~min}$ and centrifuged at 13,000 rpm for 5 min at $4{ }^{\circ} \mathrm{C}$. The supernatant $(300 \mu \mathrm{L})$ was transferred to a fresh tube. After mixing with $750 \mu \mathrm{L}$ of ethanol, the DNA was precipitated by centrifugation at 13,000 rpm for $2 \mathrm{~min}$ at $4{ }^{\circ} \mathrm{C}$. The pellet was washed with $70 \%$ ethanol, air-dried in a laminar flow cabinet and dissolved in $50 \mu \mathrm{L}$ of Tris-EDTA (TE) buffer containing $10 \mathrm{mM}$ of Tris- $\mathrm{HCl}$ and $1 \mathrm{mM}$ of EDTA (pH 8.0).

To amplify a partial fragment of the CYP51 gene from genomic DNA, the polymerase chain reaction (PCR) primers specific for $V$. nashicola, Vn51seqF (5'-ATGGGACTCCTCTCTG CTCTCCTC-3'), Vn51seqF2 (5'-GCGCTTCTCATGGCCGGTCA-3'), and Vn51seqR (5' CTATGATGATGACTTCTCTCTGCGT-3') were designed by H. J. Cools in this study based on the nucleotide sequence of the National Center for Biotechnology Information (NCBI) GenBank accession: AJ314649 [25]. The $50 \mu \mathrm{L}$ of PCR mixture contained $1 \mu \mathrm{L}$ of genomic DNA, a set of forward (Vn51seqF or Vn51seqF2) and reverse (Vn51seqR) primers $(0.2 \mu \mathrm{M}$ for each), DNase-free water, and premixed Go Taq Green Master Mix (Promega, Madison, WI, USA). PCR was performed in a TaKaRa PCR thermal cycler (TaKaRa Bio, Kusatsu, Siga, Japan) or a Mastercycler nexus gradient (Eppendorf, Hamburg, Germany) programmed for $5 \mathrm{~min}$ at $94{ }^{\circ} \mathrm{C}$, followed by 40 cycles of $1 \mathrm{~min}$ at $94{ }^{\circ} \mathrm{C}, 1.5 \mathrm{~min}$ at $50{ }^{\circ} \mathrm{C}$ or $60{ }^{\circ} \mathrm{C}$, $2 \mathrm{~min}$ at $72{ }^{\circ} \mathrm{C}$, a final extension for $4 \mathrm{~min}$ at $72{ }^{\circ} \mathrm{C}$ and holding at $4{ }^{\circ} \mathrm{C}$. PCR products were separated by electrophoresis on a 1.5\% agarose gel in TAE (40 mM Tris, $20 \mathrm{mM}$ of acetic acid, and 1mM of EDTA) buffer and stained with GelRed ${ }^{\mathrm{TM}}$ (Biotium, Hayward, CA, USA). PCR products, 1,688 bp (Vn51seqF and Vn51seqR) and $674 \mathrm{bp}$ (Vn51seqF2 and Vn51seqR) in size, respectively, were cleaned using ExoSAP-IT (Affymetrix, Santa Clara, CA, USA) according to the instructions supplied by the manufacturer. Sequencing was conducted at Macrogen Japan (Kyoto, Japan) using the same primers as for PCR. After sequencing, the nucleotide and deduced amino-acid sequences were analysed with the NCBI/GenBank database (accession: AJ314649 and CAC85409, respectively) and using basic local alignment search tools (BLAST). 


\section{Results}

\subsection{Baseline Sensitivity to Difenoconazole and Hexaconazole in Culture}

$\mathrm{EC}_{50}$ values of difenoconazole and hexaconazole were of $0.023 \pm 0.142 \mathrm{mg} / \mathrm{L}$ and $0.007 \pm 0.016 \mathrm{mg} / \mathrm{L}$ (average and $95 \% \mathrm{CI}$ ), respectively, when tested using 56 stock isolates originating from an orchard in China that had not received DMI applications. $\mathrm{EC}_{50}$ values of fenarimol, retested in this study, ranged from $0.050 \mathrm{mg} / \mathrm{L}$ to $1.038 \mathrm{mg} / \mathrm{L}$ with $0.142 \pm 0.215 \mathrm{mg} / \mathrm{L}$ (average and 95\% CI). These values represent baseline sensitivity. The average $\mathrm{EC}_{50}$ value of difenoconazole and hexaconazole was $0.017 \mathrm{mg} / \mathrm{L}$ and $0.009 \mathrm{mg} / \mathrm{L}$, respectively, for baseline Korean isolates [30] and equivalent to the values shown in this study. No geographic variation was found in the baseline sensitivity between Chinese and Korean isolates.

\subsection{Demonstration of Fenarimol Resistance in Planta and in Culture}

In a preliminary test conducted in 2005, two applications of fenarimol, sprayed 1 day before and 2 weeks after inoculation, controlled scab completely on trees inoculated with reference conidia from the NIAES. However, the control was $23.1 \%, 21.4 \%$, and $21.1 \%$ on trees inoculated with conidia from the commercial orchards at Kurume, Ninaibaru, and Chikuzen in Fukuoka Pref., respectively. Decrease in fenarimol efficacy was clearly shown in inoculation tests carried out two times in the same year (Table 1 and Figure 1). High control of $94.6 \%$ was obtained against reference conidia from the NIAES. $100 \%$ control was recorded when conidia from Tagawa were inoculated. In contrast, values of the control were significantly lower and ranged from $2.1 \%$ to $77.7 \%$ when conidia from Ukiha 2, Kurokawa, Ukiha 1, Chikuzen, and Ninaibaru were inoculated.
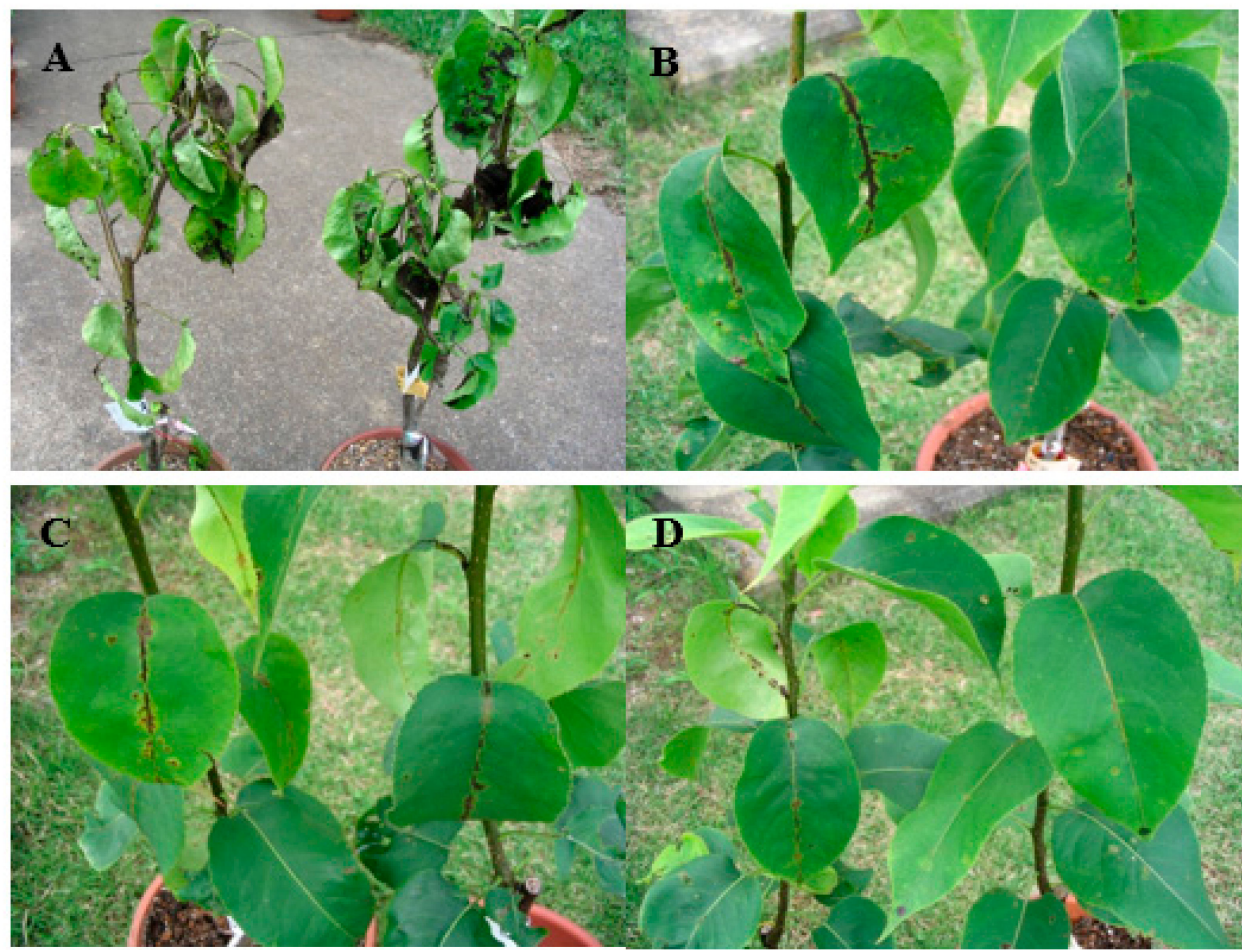

Figure 1. Control efficacy of fenarimol (on the right of each photo) sprayed preventatively and curatively at $30 \mathrm{mg} / \mathrm{L} \mathrm{AI}$ against scab disease on potted Japanese pear trees (cultivar: Kousui). Distilled water was sprayed as a reference (on the left of each photo). Trees were inoculated with the conidial suspensions prepared from (A) naturally occurring sporulating lesions collected from Ukiha 2, (B) the single-spore isolate Kurokawa 21 produced in culture, (C) the single-spore isolate Kurokawa 22 produced in culture, and (D) naturally occurring sporulating lesions collected from the NIAES. Photos were taken one month after inoculation. 
Table 1. Sensitivity of Venturia nashicola isolates to fenarimol in planta and in culture.

\begin{tabular}{|c|c|c|c|}
\hline $\begin{array}{l}\text { Year of } \\
\text { Isolation }\end{array}$ & Location & $\begin{array}{l}\text { Sensitivity to Fenarimol in Planta } \\
\text { (Control, \%) }\end{array}$ & $\begin{array}{l}\text { Sensitivity to Fenarimol in Culture } \\
\left.\text { (Average } \mathrm{EC}_{50}, \mathrm{mg} / \mathrm{L}\right)^{2}\end{array}$ \\
\hline \multirow[t]{8}{*}{2005} & Ukiha 2, Fukuoka & $2.1^{*}$ & 0.227 \\
\hline & Kurokawa, Fukuoka & $3.7 *$ & 1.012 \\
\hline & Ukiha 1, Fukuoka & $21.6^{*}$ & 0.328 \\
\hline & Chikuzen, Fukuoka & $37.8 *$ & 0.147 \\
\hline & Kurume, Fukuoka & 55.3 & 0.370 \\
\hline & Ninaibaru, Fukuoka & $77.7^{*}$ & 0.292 \\
\hline & Tagawa, Fukuoka & 100 & 0.253 \\
\hline & NIAES, Ibaraki ${ }^{3}$ & 94.6 & 0.142 \\
\hline \multirow[t]{6}{*}{2006} & Usui, Fukuoka & 25.0 & 0.233 \\
\hline & Kaho, Fukuoka & 31.7 & 0.186 \\
\hline & Akizuki, Fukuoka & 32.4 & 0.196 \\
\hline & Akaike, Fukuoka & 37.4 & 0.278 \\
\hline & Kurokawa, Fukuoka & 70.1 & 3.945 \\
\hline & NIAES, Ibaraki ${ }^{3}$ & 100 & 0.142 \\
\hline
\end{tabular}

${ }^{1}$ Conidial suspensions prepared from naturally occurring sporulating lesions were inoculated on the leaves of fenarimol ( $\left.30 \mathrm{mg} \mathrm{AI} / \mathrm{L}\right)$ treated and untreated pear trees. Control (\%) was calculated based on the scab incidence. ${ }^{2}$ Forty-one to 52 single-spore isolates from each location were used for the mycelial growth tests. $\mathrm{EC}_{50}$ means $50 \%$ effective concentration to inhibit growth. ${ }^{3}$ Sensitive reference. * Significantly different from the value of control (\%) against the reference National Institute for Agro-Environmental Sciences (NIAES) isolates based on comparison of the average and $95 \%$ confidence intervals (CIs).

In 2005 and 2006, 41 to 52 single-spore pure isolates were established from each of 7 orchards in Fukuoka mentioned above, and their sensitivity to fenarimol was tested in culture. The average $\mathrm{EC}_{50}$ values of this DMI varied from $0.147 \mathrm{mg} / \mathrm{L}$ for the isolates from Chikuzen to $1.012 \mathrm{mg} / \mathrm{L}$ for those from Kurokawa (Table 1). All of these values were higher than the baseline fenarimol sensitivity of $0.120 \mathrm{mg} / \mathrm{L}$ reported previously [24] and $0.142 \mathrm{mg} / \mathrm{L}$ retested in this study. In particular, the value $1.012 \mathrm{mg} / \mathrm{L}$ for the isolates from Kurokawa exhibited approximately 7 to 8 times higher than that for the baseline although the difference was not significant statistically. To demonstrate resistance more precisely, conidia of single-spore isolates produced on cellophane culture were employed as an inoculum source rather than those collected from naturally occurring sporulating lesions. The three isolates Kurokawa 9, Kurokawa 21 and Kurokawa 22 were chosen, because $\mathrm{EC}_{50}$ value of fenarimol for these isolates was $1.067 \mathrm{mg} / \mathrm{L}, 21.299 \mathrm{mg} / \mathrm{L}$, and $5.906 \mathrm{mg} / \mathrm{L}$, respectively (Table 2), higher than the concentration of $1 \mathrm{mg} / \mathrm{L}$ to distinguish less-sensitive isolates from sensitive ones [24]. Reference conidia from the NIAES were sensitive and completely controlled by fenarimol at each time point of disease assessment (Table 3). In contrast, control efficacy of fenarimol was inferior against the two isolates Kurokawa $21(49.9 \%)$ and Kurokawa $22(0.0 \%), 3$ weeks after inoculation. The efficacy declined further against the three isolates including Kurokawa $9(20.0 \%)$ under severe disease pressure 1 month after inoculation (Table 3). DMI resistance was thus confirmed in planta for the first time using single-spore isolates.

Table 2. Collection information, DMI sensitivity, and deduced amino-acid change of CYP51 for the representative singlespore isolates of Venturia nashicola used in this study.

\begin{tabular}{|c|c|c|c|c|c|}
\hline Isolate & $\begin{array}{l}\text { Year of } \\
\text { Isolation }\end{array}$ & Location & $\begin{array}{c}\text { Response to Fenarimol } \\
\text { or Difenoconazole in } \\
\text { Culture }\end{array}$ & $\begin{array}{l}\text { Sensitivity to Fenarimol } \\
\text { or Difenoconazole in } \\
\text { Culture }\left(\mathrm{EC}_{50}, \mathrm{mg} / \mathrm{L}\right)^{2}\end{array}$ & $\begin{array}{c}\text { Deduced Amino-Acid Change } \\
\text { of CYP51 }\end{array}$ \\
\hline Kurokawa 4 & 2005 & Asakura, Fukuoka & Sensitive & 0.151 & Q359 (-), G428R \\
\hline Kurokawa 39 & 2005 & Asakura, Fukuoka & Sensitive & 0.166 & Q359 (-), G428R \\
\hline Kurokawa 18 & 2005 & Asakura, Fukuoka & Less-sensitive & 1.948 & Y102N, D291G, Q359 (-), G445D \\
\hline Kurokawa 20 & 2005 & Asakura, Fukuoka & Less-sensitive & 0.504 & Y102N, A340T, Q359 (-), R366P \\
\hline Kurokawa 26 & 2005 & Asakura, Fukuoka & Less-sensitive & 1.970 & Y102N, Q110H, V131F \\
\hline Kurokawa 9 & 2005 & Asakura, Fukuoka & Resistant $^{3}$ & 1.067 & Q359 (-), G428R \\
\hline Kurokawa 21 & 2005 & Asakura, Fukuoka & Resistant & 21.299 & G60S, Y102N, Q359 (-), G428R \\
\hline
\end{tabular}


Table 2. Cont.

\begin{tabular}{|c|c|c|c|c|c|}
\hline Isolate & $\begin{array}{l}\text { Year of } \\
\text { Isolation }\end{array}$ & Location & $\begin{array}{c}\text { Response to Fenarimol } \\
\text { or Difenoconazole in } \\
\text { Culture }\end{array}$ & $\begin{array}{l}\text { Sensitivity to Fenarimol } \\
\text { or Difenoconazole in } \\
\text { Culture }\left(\mathrm{EC}_{50}, \mathrm{mg} / \mathrm{L}\right)^{2}\end{array}$ & $\begin{array}{c}\text { Deduced Amino-Acid Change } \\
\text { of CYP51 }\end{array}$ \\
\hline Kurokawa 22 & 2005 & Asakura, Fukuoka & Resistant & 5.906 & $\begin{array}{c}\text { Y102N, S310P, P324S, Q359 (-), } \\
\text { G428R }\end{array}$ \\
\hline 2 Housui 1 & 2017 & Imari, Saga & Sensitive & 0.003 & Q359 (-) \\
\hline 1 Housui 9 & 2017 & Imari, Saga & Less-sensitive & 0.884 & Q359 (-) \\
\hline 1 Housui 18 & 2017 & Imari, Saga & Less-sensitive & 2.675 & Q359 (-) \\
\hline 1 Housui 21 & 2017 & Imari, Saga & Less-sensitive & 1.125 & Q359 (-) \\
\hline 2 Housui 10 & 2017 & Imari, Saga & Less-sensitive & 0.551 & Not tested \\
\hline 2 Housui 14 & 2017 & Imari, Saga & Less-sensitive & 0.526 & Q359 (-) \\
\hline 2 Housui 24 & 2017 & Imari, Saga & Less-sensitive & 0.512 & Q359 (-) \\
\hline 1 Housui 13 & 2017 & Imari, Saga & Resistant & 0.619 & Q359 (-) \\
\hline 2 Housui 11 & 2017 & Imari, Saga & Resistant & 0.033 & Not tested \\
\hline H Mizu 3 & 2018 & Yame, Fukuoka & (Sensitive) & $(0.000)$ & Q359 (-) \\
\hline H Mizu 5 & 2018 & Yame, Fukuoka & (Sensitive) & $(0.044)$ & Q359 (-) \\
\hline S Mizu 2 & 2018 & Yame, Fukuoka & (Less-sensitive) & $(1.104)$ & Q359 (-), Y446H \\
\hline S Mizu 3 & 2018 & Yame, Fukuoka & (Less-sensitive) & $(0.196)$ & Q359 (-) \\
\hline S Mizu 4 & 2018 & Yame, Fukuoka & (Less-sensitive) & $(0.257)$ & Q359 (-), Y446H \\
\hline S Mizu 5 & 2018 & Yame, Fukuoka & (Less-sensitive) & $(0.593)$ & Q359 (-) \\
\hline
\end{tabular}

${ }^{1}$ Response to difenoconazole is shown in parenthesis. ${ }^{2} \mathrm{EC}_{50}$ value of difenoconazole is shown in parenthesis. ${ }^{3}$ Determined based on reduction in fungicide efficacy in planta.

Table 3. Control efficacy of fenarimol (30 mg AI/L) on single-spore isolates of Venturia nashicola in planta.

\begin{tabular}{|c|c|c|c|}
\hline Isolate & $\begin{array}{l}\text { Time After } \\
\text { Inoculation }\end{array}$ & Control (\%) & $\begin{array}{c}\text { Scab Incidence (\%) on } \\
\text { DW-Sprayed Reference Trees }\end{array}$ \\
\hline \multirow[t]{2}{*}{ Kurokawa 9} & 3 weeks & 85.7 & 93.3 \\
\hline & 1 month & 20.0 & 100.0 \\
\hline \multirow[t]{2}{*}{ Kurokawa 21} & 3 weeks & 49.9 & 93.3 \\
\hline & 1 month & 6.7 & 100.0 \\
\hline \multirow[t]{2}{*}{ Kurokawa 22} & 3 weeks & 0.0 & 86.7 \\
\hline & 1 month & 0.0 & 100.0 \\
\hline \multirow[t]{2}{*}{ NIAES $^{1}$} & 3 weeks & 100.0 & 33.3 \\
\hline & 1 month & 100.0 & 73.3 \\
\hline
\end{tabular}

${ }^{1}$ Conidia directly collected from naturally occurring sporulating lesions.

\subsection{Inconsistency of Fenarimol Sensitivity Between in Planta and in Culture Tests}

Fenarimol resistance was clearly demonstrated as above. Despite that, however, $\mathrm{EC}_{50}$ values for most of the other isolates from Kurokawa remained less than $1 \mathrm{mg} / \mathrm{L}$, the discriminatory concentration. Moreover, no statistical difference was observed in average $\mathrm{EC}_{50}$ values for the isolates grouped based on sampling orchards (Table 1). It is important to note that the high $\mathrm{EC}_{50}$ values for some less-sensitive isolates influenced wide $95 \%$ CIs. The $\mathrm{EC}_{50}$ value of fenarimol was $0.328 \pm 0.054 \mathrm{mg} / \mathrm{L}$ and $0.227 \pm 0.047 \mathrm{mg} / \mathrm{L}$, respectively, for isolates from Ukiha 1 and Ukiha 2, but control by fenarimol was only $21.6 \%$ and $2.1 \%$, respectively, in inoculation tests (Table 1). Conversely, the $\mathrm{EC}_{50}$ value was $0.292 \pm 0.056 \mathrm{mg} / \mathrm{L}$ and $0.253 \pm 0.067 \mathrm{mg} / \mathrm{L}$, respectively, for isolates from Ninaibaru and Tagawa. The conidia from these orchards were controlled $77.7 \%$ and $100 \%$, respectively (Table 1). Thus, results from mycelial growth tests in culture were inconsistent with those from inoculation tests in planta.

In 2006, results from the inoculation tests using conidia sampled in the same year indicated decrease in fenarimol efficacy. The fungicide controlled $70.1 \%$ and $100 \%$, against conidia from Kurokawa and the NIAES, respectively, whereas the control was only $25.0 \%$, $31.7 \%, 32.4 \%$, and $37.4 \%$, respectively, against those from Usui, Kaho, Akizuki, and Akaike, Fukuoka Pref. (Table 1). In the trial, disease pressure was moderate to high because scab incidence ranged from $23.1 \%$ to $53.3 \%$ on DW-sprayed reference trees. For single-spore isolates from Kurokawa, reduced fenarimol sensitivity was obvious because the average 
$\mathrm{EC}_{50}$ value was $3.945 \mathrm{mg} / \mathrm{L}$, exceeded 30 times higher than the baseline sensitivity in culture (Table 1). However, the value was $0.233 \mathrm{mg} / \mathrm{L}, 0.186 \mathrm{mg} / \mathrm{L}, 0.196 \mathrm{mg} / \mathrm{L}$, and $0.278 \mathrm{mg} / \mathrm{L}$, respectively, for the isolates from Usui, Kaho, Akizuki, and Akaike, which was less than the discriminative concentration of $1 \mathrm{mg} / \mathrm{L}$ (Table 1).

In 2017, 99 single-spore isolates, 19 to 20 for each, were established from five orchards in Imari, Saga Pref. and their sensitivity to fenarimol was examined in culture. The EC 50 values were $2.675 \mathrm{mg} / \mathrm{L}$ and $1.125 \mathrm{mg} / \mathrm{L}$, respectively, higher than the baseline for the two isolates, 1 Housui 18 and 1 Housui 21 (Table 2), but the values were lower than $1 \mathrm{mg} / \mathrm{L}$ for all of the other isolates. In the inoculation tests performed in 2018, however, sprays of fenarimol revealed $100 \%$ control against the isolate 1 Housui 18 . Furthermore, no efficacy $(-100 \%$ and $-42.8 \%$ control) was recorded on the other two isolates, 1 Housui 13 and 2 Housui 11 (Table 2), respectively. Results from in planta tests did not coincide well with those from mycelial growth tests in culture. Therefore, the following three tests were carried out to interpret the inconsistency of both results.

\subsection{Possible Source of the Inconsistency between in Planta and in Culture Tests}

In 2007, infected leaves were collected from five trees grown in the middle and four corners in an orchard located in Ninaibaru, Fukuoka. Test (1) one single lesion was selected for each tree and conidial suspensions directly prepared from the lesion were used for droplet-inoculation onto leaves of potted trees sprayed with fenarimol preventatively. Control efficacy varied considerably $(-100 \%,-60.1 \%,-14.1 \%, 0.0 \%$, and $44.5 \%$ ) suggesting irregular distribution of resistant isolates in the orchard tested. Test (2) soon after inoculation, 61 single-spore isolates were isolated from the same five lesions used as inoculum, and were tested for their fenarimol sensitivity in culture. Results showed that $\mathrm{EC}_{50}$ values were less than $1 \mathrm{mg} / \mathrm{L}$, the discriminative concentration, for all of the isolates except only one isolate. Test (3) single-spore isolation was further conducted using the lesions newly produced by inoculation mentioned above and sensitivity of isolates was examined in culture again. Fifty-six and 71 isolates from fenarimol- and DW-treated leaves, five for each, respectively, were used for the tests. Very surprisingly, $\mathrm{EC}_{50}$ values of fenarimol were less than $1 \mathrm{mg} / \mathrm{L}$ for all of the 127 isolates irrespective of where they derived, i.e., either from fenarimol-treated leaves or from DW-treated leaves. It was strongly suggested that results from mycelial growth tests in culture are not very reliable for determining DMI sensitivity of this fungus.

\subsection{Change of Cross-Resistance Pattern among DMI Fungicides with Time}

In inoculation tests, reference conidia from the NIAES were controlled $100 \%$ by fenarimol, difenoconazole, and hexaconazole 3 weeks after inoculation (Table 4). Control efficacy of fenarimol on the conidia from Kurokawa was as low as 33.2\% but both difenoconazole and hexaconazole completely controlled these conidia. However, 1 month after inoculation, sharp decrease occurred in the efficacy of fenarimol and hexaconazole but difenoconazole was still highly effective. Difenoconazole was superior to the other two DMIs at this stage in 2005 and incomplete cross-resistance among the three fungicides was thus found in planta.

Cross-resistance was further examined in culture using eight single-spore isolates including the three isolates (Kurokawa 9, Kurokawa 21, and Kurokawa 22) that showed resistance to fenarimol in planta as above (Table 3). The isolates Kurokawa 4, Kurokawa 9, Kurokawa 20, and Kurokawa 39 (Table 2) were sensitive to both difenoconazole and hexaconazole because $\mathrm{EC}_{50}$ values of these fungicides were within the range of baseline (Table 5). In contrast, the isolate Kurokawa 22 for which the $\mathrm{EC}_{50}$ of fenarimol was $5.906 \mathrm{mg} / \mathrm{L}$, showed reduced sensitivity to difenoconazole and hexaconazole. Sensitivity of the isolates Kurokawa 18, Kurokawa 21, Kurokawa 22, and Kurokawa 26 was lower to hexaconazole. 
Table 4. Control efficacy of the three DMI fungicides against Venturia nashicola conidia in planta.

\begin{tabular}{|c|c|c|c|c|}
\hline \multirow{2}{*}{$\begin{array}{c}\text { Timing of Disease Assessment } \\
3 \text { weeks after inoculation }\end{array}$} & \multirow{2}{*}{$\begin{array}{c}\text { Origin of Conidia Inoculated } \\
\text { Kurokawa }\end{array}$} & \multirow{2}{*}{$\begin{array}{c}\text { Treatment } \\
\text { Fenarimol }^{1}\end{array}$} & \multicolumn{2}{|c|}{ Scab Incidence (\%) } \\
\hline & & & 33.2 & 19.5 \\
\hline & & Difenoconazole $^{2}$ & 100 & 0.0 \\
\hline & & Hexaconazole $^{3}$ & 100 & 0.0 \\
\hline & & \multicolumn{2}{|c|}{ Distilled water } & 29.2 \\
\hline & NIAES & Fenarimol & 100 & 0.0 \\
\hline & & Difenoconazole & 100 & 0.0 \\
\hline & & Hexaconazole & 100 & 0.0 \\
\hline & & Distille & & 17.9 \\
\hline \multirow[t]{8}{*}{1 month after inoculation } & Kurokawa & Fenarimol & -14.7 & 88.4 \\
\hline & & Difenoconazole & 100 & 0.0 \\
\hline & & Hexaconazole & 21.7 & 60.4 \\
\hline & & \multicolumn{2}{|c|}{ Distilled water } & 77.1 \\
\hline & \multirow{4}{*}{ NIAES } & Fenarimol & 65.9 & 20.9 \\
\hline & & Difenoconazole & 100 & 0 \\
\hline & & Hexaconazole & 90.9 & 5.6 \\
\hline & & Distille & & 61.3 \\
\hline
\end{tabular}

${ }^{1} 30 \mathrm{mg} \mathrm{AI} / \mathrm{L} .{ }^{2} 25 \mathrm{mg} \mathrm{AI} / \mathrm{L} .{ }^{3} 10 \mathrm{mg} \mathrm{AI} / \mathrm{L}$.

Table 5. Sensitivity of Venturia nashicola isolates to the three DMI fungicides in culture.

\begin{tabular}{cccc}
\hline Isolate & \multicolumn{2}{c}{$\mathbf{E C}_{\mathbf{5 0}}(\mathbf{m g} / \mathbf{L})$ of Fungicide } & \\
\hline & Fenarimol & Difenoconazole & Hexaconazole \\
\hline Kurokawa 4 & 0.151 & $<0.010$ & 0.020 \\
Kurokawa 9 & 1.067 & $<0.010$ & $<0.010$ \\
Kurokawa 18 & 1.948 & $<0.010$ & 0.072 \\
Kurokawa 20 & 0.504 & $<0.010$ & 0.023 \\
Kurokawa 21 & 21.299 & 0.032 & 0.113 \\
Kurokawa 22 & 5.906 & 3.199 & 0.091 \\
Kurokawa 26 & 1.970 & $<0.010$ & 0.028 \\
Kurokawa 39 & 0.166 & $<0.010$ & 0.022 \\
Baseline & $0.142 \pm 0.215$ & $0.023 \pm 0.142$ & $0.007 \pm 0.016$ \\
\hline
\end{tabular}

In 2007, the conidia collected from five orchards in Imari, Saga Pref. were inoculated resulting in the control ranging from $-22.7 \%$ to $36.7 \%$ for hexaconazole. In contrast, difenoconazole gave $71.4 \%$ to $100 \%$ control. These differences were significant based on comparison of the averages and their 95\% CIs, $17.7 \pm 21.04 \%$ (hexaconazole) and $88.4 \pm 11.26 \%$ (difenoconazole), respectively, suggesting that difenoconazole was still effective at this stage in the fields although the efficacy of hexaconazole proved to decline largely. Next, single-spore isolates from these orchards in Imari were examined. Sensitivity to difenoconazole was not different significantly among the isolates but the average $\mathrm{EC}_{50}$ value of $0.260 \mathrm{mg} / \mathrm{L}$ was higher for isolates from 1 orchard than that for isolates from the other orchards. This result might have been an early sign of sensitivity shift for difenoconazole to resistance. In inoculation tests performed in 2008 using the conidia from Ninaibaru, Yasu, and Takagi, Fukuoka Pref., control efficacy of hexaconazole was 5.6, 7.9, and 91.5\%, respectively, clearly indicating the lack of efficacy of this fungicide against the former two samples. On the contrary, difenoconazole revealed $84.0 \%, 90.9 \%$, and $100 \%$ control, respectively, against these conidia. Hexaconazole and difenoconazole exhibited 77.4 and 100\% control, respectively, against reference conidia from the NIAES. These results suggest that distribution of the hexaconazole-resistant isolates differed within the same prefectures.

In 2011, conidia collected from five leaves each of three commercial orchards in Yasu, Yasukawa, and Ninaibaru, Fukuoka and an experimental orchard in the Fruit Tree Research Institute, Uki, Kumamoto (FTRI) were droplet-inoculated on leaves of DMI- or DW-pretreated potted trees. Difenoconazole gave $100 \%$ and $97.8 \%$ control against the 
conidia from both Yasu and FTRI, respectively. In contrast, the control was $44.4 \%$ and $15.5 \%$, significantly lower against the conidia from Yasukawa and Ninaibaru, respectively. Hexaconazole revealed no efficacy against the isolates from Yasu, Yasukawa, and Ninaibaru but exhibited $48.9 \%$ control against the isolates from the FTRI although this difference was not significant. Similar incomplete cross-resistance was recognized later when the single-spore isolate 2 Housui 1 was inoculated where difenoconazole revealed $100 \%$ control but fenarimol showed no efficacy (data not shown).

Most recently in 2018, 19 single-spores were isolated individually from lesions formed on leaves of inoculated pear trees after treatment with difenoconazole. The inoculum was sampled from 2 orchards in Yame, Fukuoka Pref. The $\mathrm{EC}_{50}$ of difenoconazole for 6 of 19 isolates ranged from $0.168 \mathrm{mg} / \mathrm{L}$ to $1.104 \mathrm{mg} / \mathrm{L}$. These isolates were regarded as less-sensitive because the values were significantly higher than $0.001 \mathrm{mg} / \mathrm{L}$ for the reference isolate Yasato 2-1-1 [24] and the baseline $0.023 \pm 0.142 \mathrm{mg} / \mathrm{L}$ as described above. Difenoconazole sensitivity of the other 13 isolates was within the range of baseline ranging from $0.001 \mathrm{mg} / \mathrm{L}$ to $0.154 \mathrm{mg} / \mathrm{L}$ ). In inoculation tests conducted in 2018 and 2019, the two single-spore isolates 2 Housui 14 and 2 Housui 11 (Table 2), both isolated from Imari in 2017, were regarded as sensitive and resistant to difenoconazole, respectively, because control efficacy was $100 \%$ and $-42.8 \%$ against these isolates, respectively.

\subsection{Instability of Resistance}

Mycelial growth tests were repeated on fenarimol-amended and unamended PDA using eight single-spore isolates collected from Kurokawa, Fukuoka, in 2005. As a result, except for the isolate Kurokawa 22, $\mathrm{EC}_{50}$ values of fenarimol decreased for all of the seven other isolates after storage in the absence of the fungicide (Table 6). Noticeably, the value for the isolate Kurokawa 21 decreased from $21.300 \mathrm{mg} / \mathrm{L}$ in the $1 \mathrm{st}$ trial to $1.721 \mathrm{mg} / \mathrm{L}$ in the 2nd trial, respectively. To confirm the instability of resistance in culture, similar experiments were conducted in 2018 using the eight other single-spore isolates obtained in the previous year. Sensitivity to fenarimol increased in seven isolates except the isolate 1 Housui 18 for which the $\mathrm{EC}_{50}$ value changed from $2.675 \mathrm{mg} / \mathrm{L}$ to $3.264 \mathrm{mg} / \mathrm{L}$ (Figure 2).

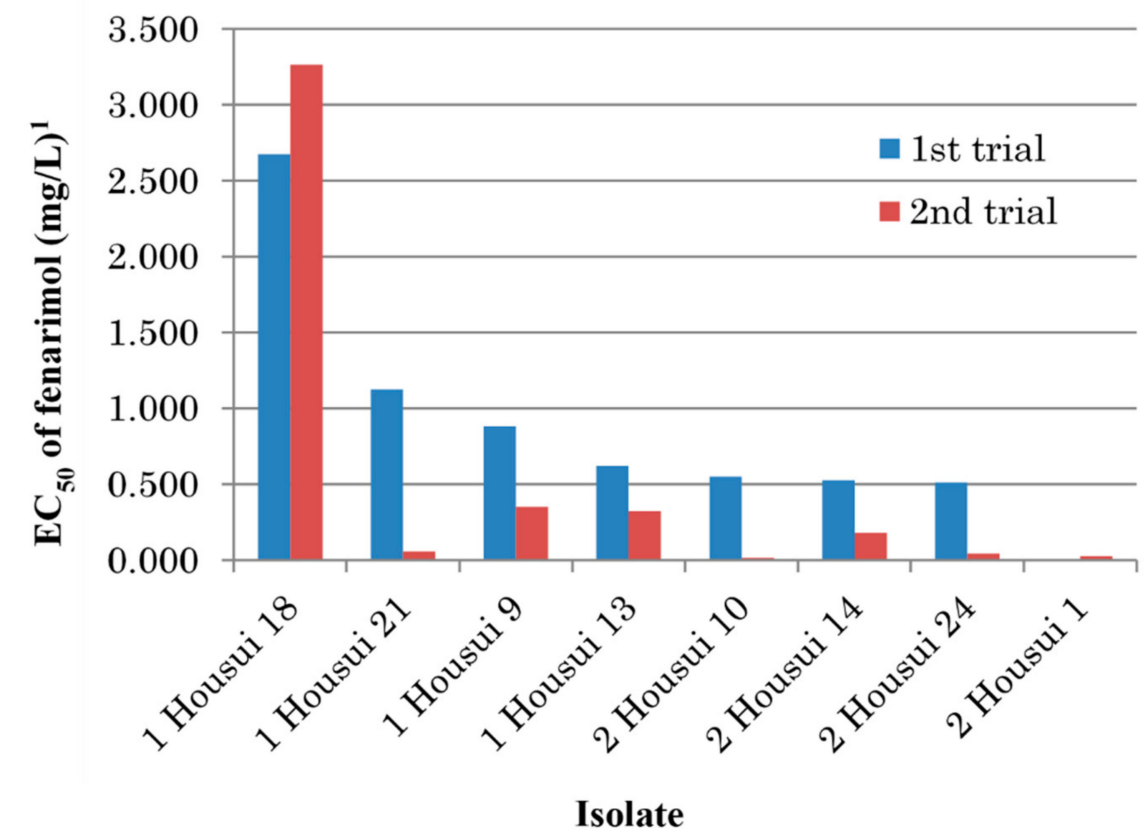

Figure 2. Change of fenarimol sensitivity in single-spore isolates of Venturia nashicola after storage at $4{ }^{\circ} \mathrm{C}$ in absence of the fungicide. ${ }^{1}$ Average values of two replicates. 
Table 6. Change of fenarimol sensitivity in single-spore isolates of Venturia nashicola after storage at $4{ }^{\circ} \mathrm{C}$ in absence of the fungicide.

\begin{tabular}{cccc}
\hline Isolate & Sensitivity to Fenarimol & \multicolumn{2}{c}{ EC $_{\mathbf{5 0}}(\mathbf{m g} / \mathbf{L})$ of Fenarimol } \\
\hline & & 1 st trial & 2nd trial \\
Kurokawa 4 & Sensitive & 0.151 & 0.028 \\
Kurokawa 39 & Sensitive & 0.166 & 0.131 \\
Kurokawa 18 & Less-Sensitive & 1.948 & 0.973 \\
Kurokawa 20 & Less-Sensitive & 0.504 & 0.347 \\
Kurokawa 26 & Less-Sensitive & 1.970 & 0.680 \\
Kurokawa 9 & Resistant $^{1}$ & 1.067 & 0.263 \\
Kurokawa 21 & Resistant $^{1}$ & 21.299 & 1.721 \\
Kurokawa 22 & Resistant $^{1}$ & 5.906 & 7.879 \\
\hline
\end{tabular}

${ }^{1}$ Reduction in fenarimol efficacy was also confirmed in planta (Table 3).

To test the stability of decreased fenarimol sensitivity, eight representative isolates previously cultured on PDA at $20^{\circ} \mathrm{C}$ in darkness for 45,60 , or 75 days, were tested for mycelial growth inhibition by transferring mycelial discs on fenarimol-amended PDA. The effect of prolonged cultivation period on the decrease in the $\mathrm{EC}_{50}$ values, i.e., recovery of the sensitivity was found in the isolate 1 Housui 18 (Figure 3).

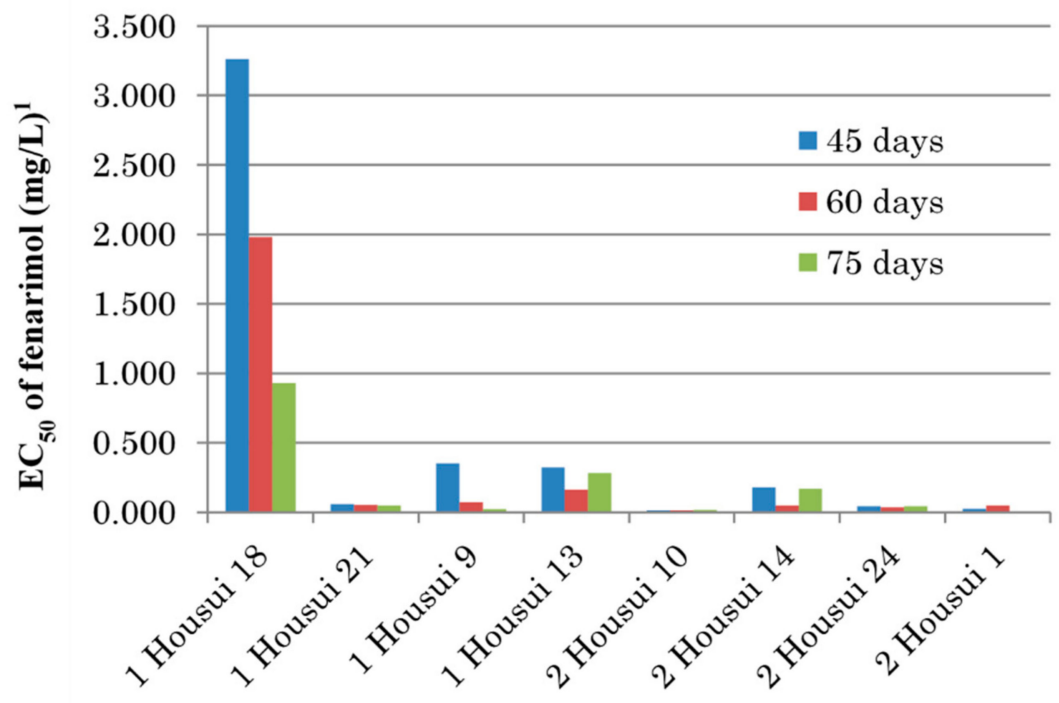

Isolate

Figure 3. Influence of precultivation period against fenarimol sensitivity in single-spore isolates of Venturia nashicola. ${ }^{1}$ Average values of two replicates.

\subsection{Sequence Analysis of CYP51 Gene}

Nucleotide sequences of the PCR amplicons from the 21 isolates used in this study (Table 2) showed 97-99\% identity with GenBank AJ314649, sequence of the CYP51 gene, encoding the DMI target sterol $14 \alpha$-demethylase protein in the wild-type sensitive isolate JS-18 of V. nashicola [25]. Sequences of the deduced amino-acids of CYP51 were compared with GenBank CAC85409 reported by Cools et al. [25] and substitution of Y102N in addition to deletion of the Q359 were found in many isolates (Table 2), indicating two differences to GenBank sequence AJ314649 in all isolates not associated with a change in DMI sensitivity. Other substitutions found in less-sensitive or resistant isolates were G60S, Q110H, V131F, D291G, S310P, A320T, P324S, R366P, G428R, and G445D.

Subsequently, substitution of the $\mathrm{Y} 446 \mathrm{H}$ was detected first from the two less difenoconazolesensitive isolates, S Mizu 2 and S Mizu 4, collected from Yame, Fukuoka Pref. in 2018 (Table 2). Deletion of the Q359 and the G428R substitution were found in isolates irrespec- 
tive of differential DMI sensitivity. Overall, genotypes of the CYP51 gene varied largely leading to amino-acid substitutions (Figure 4 and Table 7 [31-37]) distinct from each other depending on origin, i.e., year and location of sampling of the isolates.

MGLLSALLAP LAGSDRGWLF YTLASFGFTV AIVVANVLKQ VLLKNPNEPP VVFHWFPFF. 60

NTVVYGIDPI KFFAECKEKH GDIFTFILLG RKTTVYIGTK G.EFILNGK. SHVNAEEIYS 120

PLTTPVFGSD .VYDCPNSKL MEQKKFVKYG LTTEALKSYV TLIQREVEDY AKRYSQFKGE 180

KGSFDVCATM GEITIFTASR SLQGKEVRDK FDASFADLFH DLDMGFSPIN FMLPWAPLPH 240

NRRRDAANKK MTETYLEIIR SRKVEGAKKD SEDMIWNLMQ CVYKNGTPIP .NEIAHMMIA 300

LLMAGQHSS. STSSWMLFRL ATR.DIQEEL YQEQIRVCG. DLPPLKYDDL ARMPLHNQ.I 360

IKETL.MHSP IHSILRAVKQ PMPIEGTPYT IPTSHVLLAA PIASGGSPMY FPAPEKWEPH 420

RWDEGSG.TN ISGGDNGDEE KEDY..GLIT KGASSPYLPF GAGRHRCIGE QFAYMQLNTV 480

LATQVREFKF SFREGESFPK TDFSSLFSGP QRPAWLNWER REKSSS* 526

Figure 4. Translated deduced amino-acid sequence of Venturia nashicola CYP51 gene. Dots (.) indicate variants. Variants are summarized in Table $7 . *$ Stop codon.

Table 7. Amino-acid (AA) positions in CYP51 where mutations in the isolates of Venturia nashicola were sequenced. For each AA position the corresponding mutation and its eventual orthology are shown. SEPTTR: Zymoseptoria tritici; ERYSGT: Blumeria graminis f. sp. tritici; BRYSGH: Blumeria graminis f. sp. hordei; UNCINE: Erysiphe necator; MONIFG: Monilinia fructigena; LEPTNO: Parastagonospora nodorum; CERBE: Cercospora beticola. Table references: ${ }^{1}$ Stammler et al. [31]; ${ }^{2}$ Wyand and Brown [32]; ${ }^{3}$ Rallos and Baudoin [33]; ${ }^{4}$ Chen et al. [34]; ${ }^{5}$ Pereira et al. [35]; ${ }^{6}$ Cools et al. [36]; ${ }^{7}$ Spanner et al. [37].

\begin{tabular}{ccc}
\hline AA Position & Mutation & Orthology \\
\hline 60 & G60S & \\
102 & Y102N & \\
110 & Q110H & V131F is placed between D130 (SEPTTR_D134 ${ }^{1}$ ) and \\
& & Y133 (ERYSGT ${ }^{2} /$ BRYSGH $^{2} /$ UNCINE $^{3} /$ MONIFG \\
131 & V131F & \\
& & \\
291 & D291G & \\
310 & S310P & \\
324 & P324S & \\
340 & A340T & \\
359 & Q359- & \\
366 & R366P & \\
428 & G428R & SEPTTR_G460 \\
445 & G445D & CERBE_Y464 ${ }^{7}$ \\
446 & Y446H &
\end{tabular}

\section{Discussion}

The worldwide emergence of pathogens that are resistant to antifungal agents challenges human health and food security [38]. According to the Fungicide Resistance Action Committee (FRAC), DMI fungicides possess medium risk of resistance development 
(https: / / www.frac.info/, accessed on 23 June 2021) and failures of disease control against a variety of pathogens since the early 1980s have been reported. For scab control in Japanese pear, resistance has been managed mainly through restricting the number of DMI applications. Such an effort seemed to be effective as the field performance of DMIs has been maintained for about two decades. However, growers tended to spray DMIs more frequently than three times a year in some regions where disease pressure is generally high due to heavy precipitation. As a result, a decrease in fungicide efficacy became a concern and the development of resistance to fenarimol and hexaconazole was confirmed by inoculation tests. This was the first to confirm reduced DMI efficacy on scab by pathogen inoculation tests about 20 years after commencement of use in Japanese pear orchards. Resistance to hexaconazole and flusilazole was also reported in Korea where DMIs were sprayed more frequently [30].

Incomplete cross-resistance among DMIs is well known in the related fungus $V$. inaequalis, the causal agent of apple scab [39,40], and other fungi [41]. On the other hand, strong correlation of resistance to myclobutanil and tebuconazole has been found in this pathogen recently [42]. For Japanese pear scab, difenoconazole was intrinsically more active than other DMIs and the high efficacy of this fungicide was kept for years in fields where the others failed in control [22], but difenoconazole efficacy has also started to decline recently [43]. In Yame, Fukuoka Pref., where field performance of difenoconazole declined on scab, resistance development was also suspected in Gymnosporangium asiaticum, the Japanese pear rust fungus, through a retrospective cohort study [44]. Currently, the Fungicide Resistance Research Committee in the Phytopathological Society of Japan recommends limiting DMI applications within two to three times a year in a mixture with other effective fungicides carrying different mode of actions if resistant isolates have not been detected in the orchards (http:/ / www.taiseikin.jp/, accessed on 23 June 2021). Cyprodinil (FRAC code 9, anilino-pyrimidines) and iminoctadine-albesilate (FRAC code M 07, multisite inhibitor) are generally used as a partner fungicide of DMIs (FRAC code 3) in a tank mixture. QoI (FRAC code 11, quinone-outside inhibitor) and SDHI (FRAC code 7, succinate dehydrogenase inhibitor) fungicides are also sprayed in addition to some other conventional fungicides.

Detection of resistance is critical to prevent control failure and design altered spray programmes as early as possible. When testing culturable fungi for their DMI sensitivity, mycelial growth tests on fungicide-amended culture medium are most commonly used. It was the case for $V$. inaequalis $[45,46]$. However, in this study on very slow-growing $V$. nashicola, reduced DMI sensitivity was not always reproduced in replicate experiments in culture, and sensitivity was often recovered after subculture, storage and/or when the cultivation period was prolonged in the tests. The instability of in vitro DMI resistance was previously reported in other fungi including $V$. inaequalis $[47,48]$ and Monilinia fructicola $[49,50]$. For isolates of $V$. inaequalis cultured on DMI-amended PDA, reduced sensitivity to DMIfungicides was maintained. In contrast, on fungicide-free media, the sensitivity of some, but not all, isolates increased [48], which implies DMI treatment induces expression of genes involved with resistance. It is a matter of interest whether such mechanisms may incur a fitness penalty which influences stability and could result in a decline of resistance in the field.

The association of a fitness penalty with DMI resistance has not been examined for $V$. nashicola isolates. For $V$. inaequalis, DMI resistance did not seem to be related to reduced fitness [51]. On the other hand, DMI-resistant populations of $V$. inaequalis, although still present, decreased in an apple orchard 3 years after the selection pressure was removed [52]. Myclobutanil sensitivity was recovered in populations of $V$. inaequalis after delayed-dormant copper treatment [53], and in Brazil, the frequency of resistant M. fructicola isolates decreased in populations after discontinuation of tebuconazole for 3 years [54].

In addition to slow growth of mycelia, conidial production of $V$. nashicola is extremely poor on culture medium, even worse than that of $V$. inaequalis. Moreover, the incubation 
period can be as long as 3 weeks to 1 month after inoculation under optimal environmental conditions. Despite that, two different tests, i.e., in vitro mycelial growth and in planta inoculation were performed in the present study. Importantly, we noticed an inconsistency between the results from these two tests indicating that comparison of the $\mathrm{EC}_{50}$ values of DMIs for pure isolates may not be very reliable for monitoring the sensitivity of field populations. When $\mathrm{EC}_{50}$ values above those of baseline sensitivity are measured, it might indicate the existence of resistant populations in the tested field. In contrast, even if values are within the range of baseline, it is possible that some less-sensitive individuals are included as a result of false negatives which might lead to the underestimation of resistance.

Inconsistency was often found when comparing results from tests in planta with those from tests in culture, due to the instability of resistance during storage or cultivation on media. Another factor that might explain this disparity is the irregular distribution of resistant isolates in pear orchards. Ishii et al. [9] found the isolates of $V$. nashicola resistant to MBC fungicides were detected irregularly from orchards. When several sampling methods were compared, remarkable differences were detected in the proportion of resistant isolates. This is closely related with biological context such as the lifestyle of this fungus in which conidia scatter mainly by rain splash and are not disseminated over long distances [55]. It was reported that the population subdivisions of $V$. inaequalis significantly differing in their sensitivity to myclobutanil were present in same apple orchards [56].

If conventional culture methods are not appropriate to monitor fungicide resistance, molecular-based methods might be useful as alternatives for a slow-growing and poorsporulating fungus like Venturia in particular. The mechanism of MBC resistance was well characterized in $V$. nashicola $[10,57]$ and various molecular methods such as PCR-RFLP (restriction fragment length polymorphism) analysis and ASPCR (allele-specific PCR) have been developed for the diagnosis of resistance [10]. However, mechanisms of the DMI resistance are not well known yet. For the related fungus $V$. inaequalis, the mechanism has been studied. Gerberich and Beckerman [58] found resistant isolates with larger PCR amplification bands consisting of the insertion or mutations of the CYP51A1 gene and sensitive isolates with smaller amplification bands consisting of no insertions or mutations. Very recently, Yaegashi et al. [59] reported that Y137H substitution of the CYP51A was associated with low DMI sensitivity in Japanese isolates of $V$. inaequalis. In contrast, Schnabel and Jones [60] mentioned that overexpression of the target-site CYP51A1 gene was an important mechanism of resistance, but other mechanisms of resistance also appeared to exist. Villani et al. [40] found the lack of cross-resistance between myclobutanil and difenoconazole and suggested that different mechanisms may govern resistance to different DMI fungicides in this pathogen. Cools and Fraaije [61] stated that these mechanisms can combine, and levels of resistance are often determined by combinations of CYP51 amino-acid alternations, CYP51 gene overexpression and/or increased efflux. Furthermore, the combination of target-site mutations and over-expression causes a phenotype, with high levels of resistance [62].

Substitution at the equivalent amino-acid residue to Y136 and Y137 is the frequently reported CYP51 alteration in resistant isolates of both human and plant pathogenic fungi [61,63]. For $V$. nashicola, this substitution was not found but several mutations causing amino-acid substitutions or deletion such as G60S, Y102N, Q110H, V131F, D291G, S310P, A320T, P324S, Q359-, R366P, G428R, G445D, and Y446H were detected in the CYP51 gene in some but not all resistant isolates in this study. Substitutions G445D and $\mathrm{Y} 446 \mathrm{H}$ are at positions equivalent to alterations in DMI-resistant isolates of Mycosphaerella fijiensis and Zymoseptoria tritici (Mycosphaerella graminicola) $[41,64,65]$, reported to be a key mutation for azole resistance $[64,66]$. Over 30 single nucleotide polymorphisms (SNPs) have been reported in CYP51, altering the protein structure and the binding activity of fungicides [61,67]. Accumulation of mutations generated various CYP51 variants [61,68], and combination of mutations can result in alterations in the level of resistance to different DMI fungicides $[63,67]$. In the present study, the mutations leading to the substitutions such as Y102N found in less-sensitive isolates in the mid-2000s were not detected from isolates 
collected more recently in the late 2010s. Stepwise evolution of new resistant phenotypes in response to more active DMIs was reported in $M$. graminearum $[41,67]$ but point mutations of the CYP51 gene conferring DMI resistance are not very conserved in phytopathogenic fungi [39]. Therefore, it will be a future subject to examine whether these mutations are the cause of resistance and whether they can be utilized for resistance detection as a marker in $V$. nashicola.

It is most likely that other factors including increase of fungicide efflux from cells are involved in resistance. In our preliminary experiments, isolates which showed fenarimol resistance on fungicide-sprayed trees, were less-sensitive to the antibiotic cyclohexamide, an indicator of drug efflux pump activity but sensitive to chlorpromazine, a transporter modulator, in culture (Ishii et al. unpublished) indicating possible involvement of the ATP binding cassette $(\mathrm{ABC})$ transporter family [68-72] in DMI resistance of this fungus. Low uptake of penconazole due to energy-dependent efflux was found to be the mechanism of resistance to this DMI in the laboratory mutant strains of $V$. inaequalis [73].

\section{Conclusion and Future Prospects}

In $V$. nashicola, results from mycelial growth tests using fungicide-amended culture medium are not very reliable for monitoring DMI resistance and molecular diagnosis of resistance seems to still be challenging in this fungus. Therefore, it is still necessary to confirm fungicide efficacy by inoculation tests on DMI-sprayed pear trees. The novel fungicide ipflufenoquin potentially possessing a new mode of action has been registered for pear scab recently in Japan. Additionally, the new DMI fungicide mefentrifluconazole [74], effective against scab with a reportedly more favorable toxicity profile [75], is now under development. Use of these fungicides in combination with disease-resistance inducers [76] and/or newly released scab-resistant pear cultivars [4,7] will be useful for integrated scab control in future.

Author Contributions: Conceptualization, H.I.; methodology, H.I., H.J.C. and L.B.; validation, H.I., H.J.C. and L.B.; formal analysis, H.I., K.N., H.J.C. and L.B.; investigation, H.I. and K.N.; resources, K.K.; data curation, H.I., K.N., H.J.C. and L.B.; writing-original draft preparation, H.I.; writingreview and editing, H.I., H.J.C. and L.B.; supervision, Y.Y.; project administration, H.I. All authors have read and agreed to the published version of the manuscript.

Funding: There are no funders of this study.

Data Availability Statement: Not applicable.

Acknowledgments: We are grateful to Fraaije, B.A., Rothamstead Research for useful advice, and to Wang, W., Institute of Plant Protection, Hebei Academy of Agricultural and Forestry Sciences, China, Yamaguchi, M., Imari, Matsuo, E., JA Imari, Saga, and Kumamoto FTRI, for arranging sample collection. We also thank So, K., ZEN-NOH, Tokyo for supplying software, Uzuhashi, S. and Katoh, H. for technical assistance, and the field staff of the National Institute for Agro-Environmental Sciences, Tsukuba, for assistance in caring for the pear trees.

Conflicts of Interest: H.J. Cools and L. Borghi are employees of Syngenta.

\section{References}

1. Abe, K.; Saito, T.; Terai, O.; Sato, Y.; Kotobuki, K. Genotypic difference for the susceptibility of Japanese, Chinese and European pears to Venturia nashicola, the cause of scab on Asian pears. Plant Breed. 2008, 127, 407-412. [CrossRef]

2. Tanaka, S.; Yamamoto, S. Studies on pear scab. II. Taxonomy of the causal fungus of Japanese pear scab. Ann. Phytopathol. Soc. Jpn. 1964, 29, 128-136. [CrossRef]

3. Ishii, H.; Yanase, H. Venturia nashicola, the scab fungus of Japanese and Chinese pears: A species distinct from V. pirina. Mycol. Res. 2000, 104, 755-759. [CrossRef]

4. Ishii, H.; Nishimura, K.; Tanabe, K.; Yamaoka, Y. Pathogenic specialization of Venturia nashicola, causal agent of Asian pear scab, and resistance of pear cultivars Kinchaku and Xiangli. Phytopathology 2020, in press. [CrossRef]

5. Le Cam, B.; Devaux, M.; Parisi, L. Specific polymerase chain reaction identification of Venturia nashicola using internally transcribed spacer region in the ribosomal DNA. Phytopathology 2001, 91, 900-904. [CrossRef] [PubMed] 
6. EPPO. Venturia nashicola.EPPO Datasheets on Pests Recommended for Regulation. 2020. Available online: https://gd.eppo.int (accessed on 23 June 2021).

7. Ishii, H.; Kimura, Y. A new interspecific pear cultivar Yutaka: Highly resistant to the two major diseases scab and black spot on Asian pears. Eur. J. Plant Pathol. 2018, 152, 507-514. [CrossRef]

8. Saito, T. Advances in Japanese pear breeding in Japan. Breed. Sci. 2016, 66, 46-59. [CrossRef] [PubMed]

9. Ishii, H.; Udagawa, H.; Yanase, H.; Yamaguchi, A. Resistance of Venturia nashicola to thiophanate-methyl and benomyl: Build-up and decline of resistance in the field. Plant Pathol. 1985, 34, 363-368. [CrossRef]

10. Ishii, H. Resistance in Venturia nashicola to benzimidazoles and sterol demethylation inhibitors. In Fungicide Resistance in Crop Protection; Thind, T.S., Ed.; CAB International: Wallingford, UK, 2012; pp. 21-31.

11. Ziogas, B.N.; Malandrakis, A.A. Sterol biosynthesis inhibitors: C14 demethylation (DMIs). In Fungicide Resistance in Plant PathogensPrinciples and a Guide to Practical Management; Ishii, H., Hollomon, D.W., Eds.; Springer: Tokyo, Japan, 2015; pp. $199-216$.

12. Mehl, A.; Schmitz, H.; Stenzel, K.; Bloomberg, J. DMI fungicides (FRAC Code 3): Sensitivity status of key target pathogens, field versus laboratory resistance, and resistance mechanisms. In Fungicide Resistance in North America, 2nd ed.; Stevenson, K.L., McGrath, M.T., Wyenandt, C.A., Eds.; APS Press: St. Paul, MN, USA, 2019; pp. 51-68.

13. Umemoto, S. Studies on the ecology and control of Japanese pear scab. Spec. Bull. Chiba Pref. Agric. Exper. Stn. 1993, 22, 1-99. (In Japanese with English summary)

14. Loeffler, R.S.T.; Butters, J.A.; Hollomon, D.W. The sterol composition of powdery mildews. Phytochemistry 1992, $31,1561-1563$. [CrossRef]

15. Shirane, N.; Takenaka, H.; Ueda, K.; Hashimoto, Y.; Katoh, K.; Ishii, H. Sterol analysis of DMI-resistant and -sensitive strains of Venturia inaequalis. Phytochemistry 1996, 41, 1301-1308. [CrossRef]

16. Chapuis, L.; Corio-Costet, M.R.; Malosse, C. Sterol composition of the woody plant pathogenic fungus Eutypa lata. Phytochemistry 1996, 42, 1599-1601. [CrossRef]

17. Brent, J.K.; Hollomon, D.W. Fungicide Resistance in Crop Pathogens: How Can It Be Managed? FRAC Monograph No. 1 (Second, Revised Edition). 2007. Available online: https://www.frac.info/docs/default-source/publications/monographs/monograph-1 (accessed on 23 June 2021).

18. Stanis, V.F.; Jones, A.L. Reduced sensitivity to sterol-inhibiting fungicides in field isolates of Venturia inaequalis. Phytopathology 1985, 75, 1098-1101. [CrossRef]

19. Thind, T.S.; Clerjeau, M.; Olivier, J.M. First observations on resistance in Venturia inaequalis and Guignardia bidwellii to ergosterolbiosynthesis inhibitors in France. In British Crop Protection Conference. Pests and Diseases; BCPC Publications: Surrey, UK, 1986; Volume 2, pp. 491-498.

20. Köller, W.; Scheinpflug, H. Fungal resistance to sterol biosynthesis inhibitors: A new challenge. Plant Dis. 1987, 71, 1066-1074. [CrossRef]

21. Ishii, H. Resistance management in diseases of top fruit in Japan. Pestic. Sci. 1997, 51, 383-386. [CrossRef]

22. Kikuhara, K.; Ishii, H. Fenarimol resistance in Venturia nashicola, the scab fungus of Japanese pear in Fukuoka Prefecture. Kyushu Plant Prot. Res. 2008, 54, 24-29. (In Japanese with English abstract) [CrossRef]

23. Ishii, H.; Takeda, H.; Nagamatsu, Y.; Nakashima, H. Sensitivity of the pear scab fungus (Venturia nashicola) to three ergosterol biosynthesis-inhibiting fungicides. Pestic. Sci. 1990, 30, 405-413. [CrossRef]

24. Tomita, Y.; Ishii, H. Reduced sensitivity to fenarimol in Japanese field strains of Venturia nashicola. Pestic. Sci. 1998, 54, 150-156. [CrossRef]

25. Cools, H.J.; Ishii, H.; Butters, J.A.; Hollomon, D.W. Cloning and sequence analysis of the eburicol $14 \alpha$-demethylase encoding gene (CYP51) from the Japanese pear scab fungus Venturia nashicola. J. Phytopathol. 2002, 150, 444-450. [CrossRef]

26. Ishii, H.; Kikuhara, K. Occurrence of DMI resistance in Venturia nashicola, the scab fungus of Asian pears. In Proceedings of the Abstracts of the 17th Symposium of Research Committee on Fungicide Resistance, the Phytopathological Society of Japan, Utsunomiya, Japan, 31 March 2007; pp. 49-60. (In Japanese with English abstract)

27. Parker, D.M.; Hilber, U.W.; Bodmer, M.; Smith, F.D.; Yao, C.; Köller, W. Production and transformation of conidia of Venturia inaequalis. Phytopathology 1995, 85, 87-91. [CrossRef]

28. Ishii, H.; Udagawa, H.; Nishimoto, S.; Tsuda, T.; Nakashima, H. Scab resistance in pear species and cultivars. Acta Phytopathol. Entomol. Hun. 1992, 27, 293-298.

29. Saitoh, K.; Togashi, K.; Arie, T.; Teraoka, T. A simple method for a mini-preparation of fungal DNA. J. Gen. Plant Pathol. 2006, 72, 348-350. [CrossRef]

30. Kwon, S.M.; Yeo, M.I.; Choi, S.H.; Kim, G.W.; Jun, K.J.; Uhm, J.Y. Reduced sensitivities of the pear scab fungus (Venturia nashicola) collected in Ulsan and Naju to five ergosterol-biosynthesis-inhibiting fungicides. Res. Plant J. 2010, 16, 48-58. (In Korean with English abstract)

31. Stammler, G.; Carstensen, M.; Koch, A.; Semar, M.; Strobel, D.; Schlehuber, S. Frequency of different CYP51-haplotypes of Mycosphaerella graminicola and their impact on epoxiconazole-sensitivity and -field efficacy. Crop Prot. 2008, 27, $1448-1456$. [CrossRef]

32. Wyand, R.A.; Brown, J.K.M. Sequence variation in the CYP51 gene of Blumeria graminis associated with resistance to sterol demethylase inhibiting fungicides. Fungal Genet. Biol. 2005, 42, 726-735. [CrossRef] 
33. Rallos, L.E.E.; Baudoin, A.B. Co-occurrence of two allelic variants of CYP51 in Erysiphe necator and their correlation with over-expression for DMI resistance. PLoS ONE 2016, 11, e0148025. [CrossRef]

34. Chen, F.; Lin, D.; Wang, J.; Li, B.; Duan, H.; Liu, J.; Liu, X. Heterologous expression of the Monilinia fructicola CYP51 (MfCYP51) gene in Pichia pastoris confirms the mode of action of the novel fungicide, SYP-Z048. Front. Microbiol. 2015, 6, 457. [CrossRef] [PubMed]

35. Pereira, D.A.; McDonald, B.A.; Brunner, P.C. Mutations in the CYP51 gene reduce DMI sensitivity in Parastagonospora nodorum populations in Europe and China. Pest Manag. Sci. 2017, 73, 1503-1510. [CrossRef]

36. Cools, H.J.; Parker, J.E.; Kelly, D.E.; Lucas, J.A.; Fraaije, B.A.; Kelly, S.L. Heterologous expression of mutated eburicol $14 \alpha-$ demethylase (CYP51) proteins of Mycosphaerella graminicola to assess effects on azole fungicide sensitivity and intrinsic protein function. Appl. Environ. Microbiol. 2010, 76, 2866-2872. [CrossRef]

37. Spanner, R.; Taliadoros, D.; Richards, J.; Rivera-Varas, V.; Neubauer, J.; Natwick, M.; Hamilton, O.; Vaghefi, N.; Pethybridge, S.; Secor, G.A.; et al. Genome-wide association studies reveal the complex genetic architecture of DMI fungicide resistance in Cercospora beticola. bioRxiv 2020. [CrossRef]

38. Fisher, M.C.; Hawkins, N.J.; Sanglard, D.; Gurr, S.J. Worldwide emergence of resistance to antifungal drugs challenges human health and food security. Science 2018, 360, 739-742. [CrossRef]

39. Xu, X.M.; Gao, L.Q.; Yang, J.R. Are insensitivities of Venturia inaequalis to myclobutanil and fenbuconazole correlated? Crop Protect. 2010, 29, 183-189. [CrossRef]

40. Villani, S.M.; Hulvey, J.; Hily, J.M.; Cox, K.D. Overexpression of the CYP51A1 gene and repeated elements are associated with differential sensitivity to DMI fungicides in Venturia inaequalis. Phytopathology 2016, 106, 562-571. [CrossRef] [PubMed]

41. Cools, H.J.; Hawkins, N.J.; Fraaije, B. Constraints on the evolution of azole resistance in plant pathogenic fungi. Plant Pathol. 2013, 62 (Suppl. 1), 36-42. [CrossRef]

42. Cordero-Limon, L.; Shaw, M.W.; Passey, T.A.J.; Robinson, J.D.; Xu, X. Cross-resistance between myclobutanil and tebuconazole and the genetic basis of tebuconazole resistance in Venturia inaequalis. Pest Manag. Sci. 2021, 77, 844-850. [CrossRef]

43. Kikuhara, K.; Adachi, T.; Saito, N.; Iiyama, K.; Matsumoto, M.; Furuya, N. Development of resistance to DMI fungicides in Venturia nashicola, the causal agent of the Japanese pear scab, in Fukuoka Prefecture, Japan. Kyushu Plant Prot. Res. 2018, 64, 1-6. (In Japanese with English abstract) [CrossRef]

44. Kikuhara, K.; Hashimoto, F.; Matsumoto, M.; Iiyama, K.; Furuya, N. The relationship between an increase in Japanese pear rust and decreased efficacy of DMI fungicides: A retrospective cohort study in Yame region, Fukuoka Prefecture, Japan. Jpn. J. Phytopathol. 2018, 84, 98-104. (In Japanese with English abstract) [CrossRef]

45. Köller, W.; Wilcox, W.F.; Barnard, J.; Jones, A.L.; Braun, P.G. Detection and quantification of resistance of Venturia inaequalis populations to sterol demethylation inhibitors. Phytopathology 1997, 87, 184-190. [CrossRef]

46. Villani, S.M.; Biggs, A.R.; Cooley, D.R.; Raes, J.J.; Cox, K.D. Prevalence of myclobutanil resistance and difenoconazole insensitivity in populations of Venturia inaequalis. Plant Dis. 2015, 99, 1526-1536. [CrossRef]

47. Köller, W.; Smith, F.D.; Reynolds, K.L. Phenotypic instability of flusilazole sensitivity in Venturia inaequalis. Plant Pathol. 1991, 40, 608-611. [CrossRef]

48. Ishii, H.; Homma, F.; Miura, T.; Suzaki, H.; van Raak, M. Resistance of Venturia inaequalis to DMIs—Phenotypic instability and genetic control. In Proceedings of the Abstracts of the 6th International Congress of Plant Pathology, Montreal, ON, Canada, 28 June 1993; p. 92.

49. Cox, K.D.; Bryson, P.K.; Schnabel, G. Instability of propiconazole resistance and fitness in Monilinia fructicola. Phytopathology 2007, 97, 448-453. [CrossRef]

50. Zhu, F.; Bryson, P.K.; Schnabel, G. Influence of storage approaches on instability of propiconazole resistance in Monilinia fructicola. Pest Manag. Sci. 2012, 68, 1003-1009. [CrossRef] [PubMed]

51. Ortega, F.; Steiner, U.; Dehne, H.W. Differentiation of SBI resistance and parasitic fitness components in German isolates of Venturia inaequalis (Cke.) Wint and interest of induced resistance for antiresistance strategies. Med. Fac. Landbouww. Univ. Gent. 1996, 61, 413-423.

52. Braun, P.G. Development and decline of a population of Venturia inaequalis resistant to sterol-inhibiting fungicides. Norw. J. Agric. Sci. 1994, 17, 173-184.

53. Frederick, Z.A.; Villani, S.M.; Cox, K.D. The effect of delayed-dormant chemical treatments on demethylation inhibitor (DMI) sensitivity in a DMI-resistant population of Venturia inaequalis. Plant Dis. 2015, 99, 1751-1756. [CrossRef]

54. Pereira, W.V.; Morales, R.G.F.; Bauer, A.I.G.; Kudlawiec, K.; May-De-Mio, L.L. Discontinuance of tebuconazole in the field restores sensitivity of Monilinia fructicola in stone fruit orchards. Plant Pathol. 2020, 69, 68-76. [CrossRef]

55. Misonou, T.; Fukatsu, R. Studies on the infection and control of pear scab. II. Dispersion of conidia and their role as the origin of infection. Bull. Chiba Agric. Exp. Stn. 1970, 10, 91-98. (In Japanese with English summary)

56. Gao, L.; Berrie, A.; Yang, J.; Xu, X. Within- and between-orchard variability in the sensitivity of Venturia inaequalis to myclobutanil, a DMI fungicide, in the UK. Pest Manag. Sci. 2009, 65, 1241-1249. [CrossRef]

57. Kwak, Y.; Min, J.; Song, J.; Kim, M.; Lee, H.; Kim, H.T. Relationship of resistance to benzimidazole fungicides with mutation of $\beta$-tubulin gene in Venturia nashicola. Res. Plant Dis. 2017, 23, 150-158. (In Korean with English abstract) [CrossRef]

58. Gerberich, K.M.; Beckerman, J. Rapid detection of fungicide resistance in Venturia inaequalis. Phytopathology 2011, 101, S2.3. 
59. Yaegashi, H.; Hirayama, K.; Akahira, T.; Ito, T. Point mutation in CYP51A1 of Venturia inaequalis is associated with low sensitivity to sterol demethylation inhibitors. J. Gen. Plant Pathol. 2020, 86, 245-249. [CrossRef]

60. Schnabel, G.; Jones, A.L. The $14 \alpha$-demethylase (CYP51A1) gene is overexpressed in Venturia inaequalis strains resistant to myclobutanil. Phytopathology 2001, 91, 101-110. [CrossRef]

61. Cools, H.J.; Fraaije, B.A. Update on mechanism of azole resistance in Mycosphaerella graminicola and implications for future control. Pest Manag. Sci. 2013, 64, 681-684. [CrossRef] [PubMed]

62. Cools, H.J.; Bayon, C.; Atkins, S.; Lucas, J.A.; Fraaije, B.A. Overexpression of the sterol $14 \alpha$-demethylase gene (MgCYP51) in Mycosphaerella graminicola isolates confers a novel azole fungicide sensitivity phenotype. Pest Manag. Sci. 2012, 68, 1034-1040. [CrossRef]

63. Becher, R.; Wirsel, S.G.R. Fungal cytochrome P450 sterol 14 $\alpha$-demethylase (CYP51) and azole resistance in plant and human pathogens. Appl. Microbiol. Biotechnol. 2012, 95, 825-840. [CrossRef]

64. Leroux, P.; Albertini, C.; Gautier, A.; Gredt, M.; Walker, A.S. Mutations in the CYP51 gene correlated with changes in sensitivity to sterol 14 $\alpha$-demethylation inhibitors in field isolates of Mycosphaerella graminicola. Pest Manag. Sci. 2007, 63, 688-698. [CrossRef] [PubMed]

65. Mair, W.; Lopez-Ruiz, F.; Stammler, G.; Clark, W.; Burnett, F.; Hollomon, D.; Ishii, H.; Thind, T.S.; Brown, J.K.M.; Fraaije, B.; et al. Proposal for a unified nomenclature for target-site mutations associated with resistance to fungicides. Pest Manag. Sci. 2016, 72, 1449-1459. [CrossRef] [PubMed]

66. Huf, A.; Rehfus, A.; Lorenz, K.H.; Bryson, R.; Voegele, R.T.; Stammler, G. Proposal for a new nomenclature for CYP51 haplotypes in Zymoseptoria tritici and analysis of their distribution in Europe. Plant Pathol. 2018, 67, 1706-1712. [CrossRef]

67. Price, C.L.; Parker, J.E.; Warrilow, A.G.S.; Kelly, D.E.; Kelly, S.L. Azole fungicides-understanding resistance mechanisms in agricultural fungal pathogens. Pest Manag. Sci. 2015, 71, 1054-1058. [CrossRef] [PubMed]

68. Leroux, P.; Walker, A.S. Multiple mechanisms account for resistance to sterol $14 \alpha$-demethylation inhibitors in field isolates of Mycosphaerella graminicola. Pest Manag. Sci. 2011, 67, 44-59. [CrossRef]

69. De Waard, M.; Andrade, A.C.; Hayashi, K.; Schoonbeek, H.J.; Stergiopoulos, I.; Zwiers, L.H. Impact of fugal drug transporters on fungicide sensitivity, multidrug resistance and virulence. Pest Manag. Sci. 2006, 62, 195-207. [CrossRef]

70. Kretschmer, M.; Leroch, M.; Mosbach, A.; Walker, A.S.; Fillinger, S.; Mernke, D.; Schoonbeek, H.J.; Pradier, J.M.; Leroux, P.; de Waard, M.A.; et al. Fungicide-driven evolution and molecular basis of multidrug resistance in the field populations of the grey mould fungus Botrytis cinerea. PLoS Pathog. 2009, 5, e1000696. [CrossRef]

71. Leroux, P.; Walker, A.S. Activity of fungicides and modulators of membrane drug transporters in field strains of Botrytis cinerea displaying multidrug resistance. Eur. J. Plant Pathol. 2013, 135, 683-693. [CrossRef]

72. Hahn, M.; Leroch, M. Multidrug efflux transporters. In Fungicide Resistance in Plant Pathogens_Principles and a Guide to Practical Management; Ishii, H., Hollomon, D.W., Eds.; Springer: Tokyo, Japan, 2015; pp. 233-248.

73. Palani, P.V.; Lalithakumari, D. Resistance of Venturia inaequalis to the sterol biosynthesis-inhibiting fungicide, penconazole [1-(2-(2,4-dichlorophenyl)pentyl)-1H-1,2,4-triazole]. Mycol. Res. 1999, 103, 157-1164.

74. Ishii, H.; Bryson, P.K.; Kayamori, M.; Miyamoto, T.; Yamaoka, Y.; Schnabel, G. Cross-resistance to the new fungicide mefentrifluconazole in DMI-resistant fungal pathogens. Pestic. Biochem. Physiol. 2021, 171, 104737. [CrossRef]

75. Tesh, S.A.; Tesh, J.M.; Fegert, I.; Buesen, R.; Schneider, S.; Mentzel, T.; van Ravenzwaay, B.; Stinchcombe, S. Innovative selection approach for a new antifungal agent mefentrifluconazole (Revysol $\left.{ }^{\circledR}\right)$ and the impact upon its toxicity profile. Regul. Toxicol. Phamacol. 2019, 106, 152-168. [CrossRef]

76. Nakao, S.; Watanabe, H.; Yano, T.; Yamaoka, Y.; Ishii, H. Control efficacy of the systemic acquired resistance (SAR) inducer acibenzolar S methyl against Venturia nashicola in Japanese pear orchards. J. Gen. Plant Pathol. 2021. [CrossRef] 